\title{
Assessment of Water Used In Basic Schools And Its Impact on School Feeding Programme, A Case Study in Mampong Municipality
}

Richard A. Kuffour*

Department of Environmental Health and Sanitation Education, University of Education,Winneba, Mampong-Ashanti, Ghana

\begin{tabular}{|c|c|}
\hline $\begin{array}{c}\text { Article History } \\
\text { Received: } 26.08 .2020 \\
\text { Accepted: } 12.09 .2020 \\
\text { Published: } 30.09 .2020 \\
\\
\text { Journal homepage: } \\
\text { http://www.easpublisher.com/easjals/ }\end{array}$ & $\begin{array}{l}\text { Abstract: Millions of children get debilitated and pass on consistently from water, } \\
\text { sanitation, and hygiene diseases. Children's ability to learn may be affected by } \\
\text { inadequate water, sanitation, and hygiene conditions in several ways. Twenty basic } \\
\text { schools under the School Feeding Programme were randomly selected from } 10 \text { towns } \\
\text { within the Mampong Municipality. A total of } 140 \text { pupils were randomly selected from } \\
\text { the } 20 \text { schools for the study. Water samples were taken from each of the schools for their } \\
\text { physicochemical and microbial quality analyses. The findings of the study revealed that } \\
\text { most of the water used by pupils in the selected schools had microbial contamination. } \\
\text { More than } 70 \% \text { of the towns had total coliforms in water samples whilst } 50 \% \text { of the } \\
\text { samples had faecal coliforms. Half of the towns had both faecal and total coliform in } \\
\text { their water samples. Total coliform values ranged from } 0.67 \pm 0.58 \text { to } 37.67 \pm 19.66 \\
\text { cfu/100ml and faecal coliforms } 4.33 \pm 4.51-11.67 \pm 7.64 \text { cfu/100ml.All physicochemical } \\
\text { parameters were within allowable limits except pH, which were below the minimum pH } \\
\text { level in water recommended by WHO. pH levels were between } 5.02 \pm 1.59 \text { to } 6.23 \pm 0.25 \text {. } \\
\text { It appears that microbial contamination was detected were very high in the form of Total } \\
\text { and Faecal Coliform Bacteria. And water samples were slightly acidic, compared to the } \\
\text { WHO recommended guidelines. } \\
\text { Keywords: Water quality, Basic Schools, School Feeding, WASH facilities, Mampong } \\
\text { Municipality. }\end{array}$ \\
\hline
\end{tabular}

Copyright ( 2020 The Author(s): This is an open-access article distributed under the terms of the Creative Commons Attribution 4.0 International License (CC BY-NC 4.0) which permits unrestricted use, distribution, and reproduction in any medium for non-commercial use provided the original author and source are credited.

\section{INTRODUCTION}

The provision of an adequate supply of safe water was one of the eight components of primary health care identified by the International Conference on Primary Health Care in Alma-Ata in 1978 (World Health Organization, WHO, 2009). The inability to achieve MDGs related to safe water supply and sanitation has been a burden on children in most developing countries (UNICEF, 2008). Although progress had been made by most countries concerning child morbidity and mortality rate, there are still much to be done to improve child health (WHO, 2013). Preventing the spread of infectious agents in schools is a good way regarding abating infectious diseases among children and improving their health. Providing water, sanitation, and hygiene (WASH) facilities in schools are very crucial in ensuring the adoption and maintenance of safe sanitation and hygiene practices among school children (Appiah-Brempong et al. 2018). It has been established that WASH provisions in most schools in many low-income countries, are however, persistently insufficient and most often associated with ill effects on health and school attendance (Jasper et al. 2012).
Globally, drinking water has been established as a primary transmission pathway for diarrhea pathogens (Dufour, 2003; WHO, 2010). In industrialized countries, centrally treated drinking water distribution systems have largely eliminated outbreaks of waterborne diseases, such as typhoid fever and cholera (Cutler \& Miller, 2005). In developing countries, there is a large body of evidence that improving the microbial quality of drinking water by treatment and safe storage reduces diarrhea (Arnold \& Colford, 2007; Fewtrell et al. 2005).

Schools are places where children actively stay for most of the day and therefore for a healthy and conducive learning environment, children need safe water for drinking and hand washing. The high rate of diarrhea and other communicable diseases among school children is partly due to poor knowledge and practice of personal and environmental hygiene (Monney et al, 2014); poor knowledge and practice of the attitude to personal hygiene such as hand washing, have a negative consequence for child's long term 'washing development' (Crosby et al. 2020). All school 
children need good hygiene due to profound effects on school attendance and performance outcome.

The provision of quality water, sanitation, and hygiene in schools been established to improve health, boost educational achievement and promote gender equity, which has a positive impact on the health and hygiene of the pupils and the community as a whole (WHO, 2011). This study, therefore, accessed the availability, accessibility, and quality of water in schools under the School Feeding Program in Ashanti Mampong Municipality.

\section{Materials ANd Methods}

The research was conducted in Basic schools within the Mampong Municipality in the Ashanti Region of Ghana. It was also one of the thirty administrative districts in the Ashanti Region of Ghana and $55 \mathrm{Km}$ northeast of the Kumasi-Ejura road. It is bounded to the south by Sekyere South district, to the east by Sekyere Central and the North by EjuraSekyerdumasi districts. The Municipality's capital is Asante Mampong, located within longitudes $0^{0} 05 \square \mathrm{W}$ and $1^{0} 30 \square \mathrm{W}$ and latitudes $6^{0} 55 \square$ Nand $7^{0} 30 \square \mathrm{N}$ (GSS, 2010).

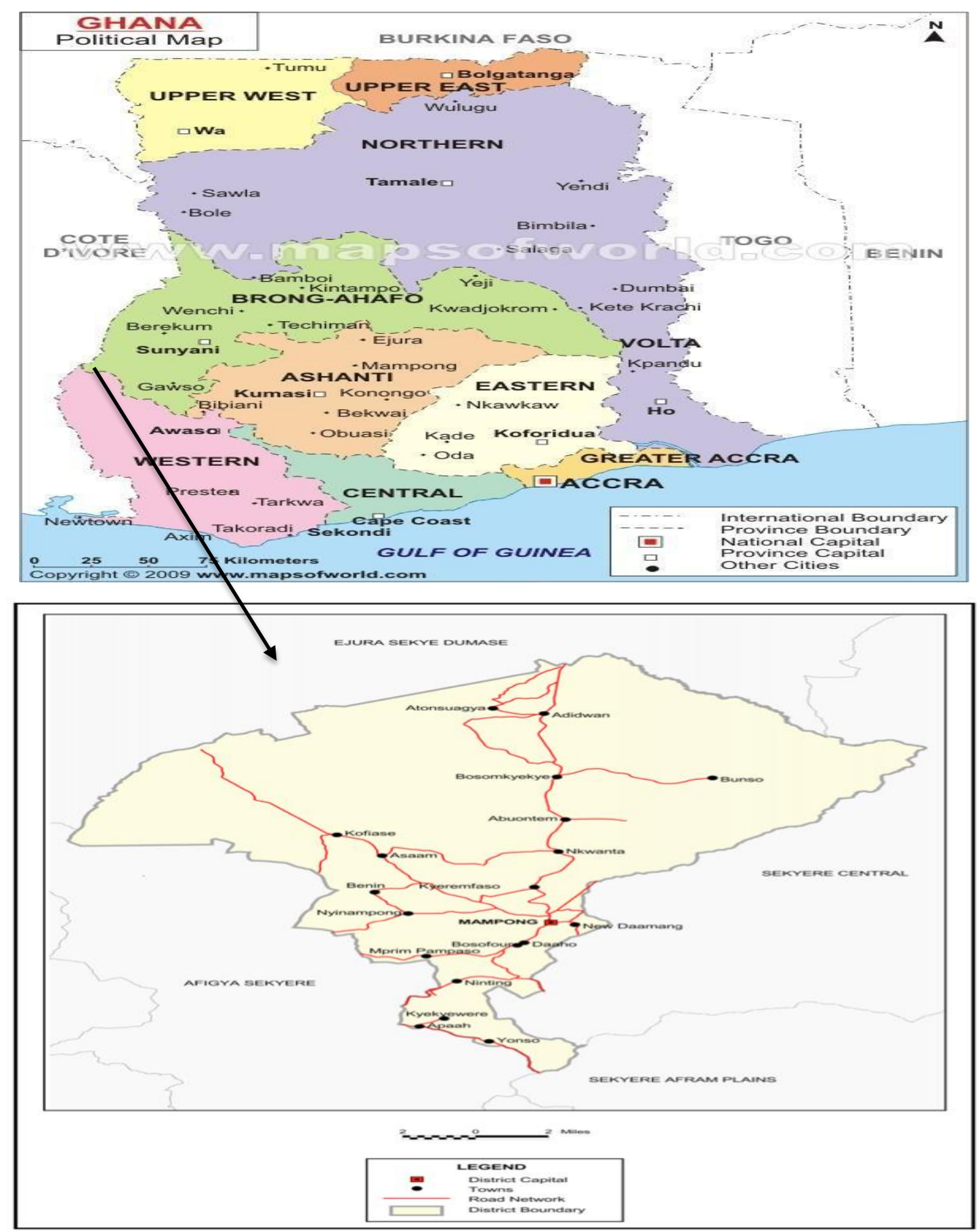

Figure 1: Map of the study area 


\section{Sample Size and Data Collection}

For the purpose of the study, purposive sampling was used to select respondents from basic schools and headteachers of basic schools under the Government of Ghana (GoG) School Feeding Programme. A total of 140 students from 20 basic schools in 10towns within Mampong Municipality, namely: Mampong, Krobo, Nyinampong, Bosofour, Ninting, Assam, Kofiase, Benim, PSK and Kyiremfaso were selected for the study. At the beginning of the study, the heads of the selected basic schools were duly informed. Before data collection started, the reason for the study and procedures for collecting data was explained to the teachers and pupils.

Data was collected from these basic schools by administering questionnaires to solicit responses on the availability and accessibility of water and WASH facilities. The head teachers of the selected basic schools were interviewed and observations were also made with regards to accessibility and availability of water and WASH facilities in the schools to support the responses received. Water samples were collected from the schools for physicochemical and microbial analyses. The physicochemical parameters analyzed were $\mathrm{pH}$, turbidity, conductivity, total dissolved solids (TDS), total hardness, and temperature, while the Total coliforms and faecal coliform were the microbial analyses conducted on the water samples. The total and faecal coliforms analyses were conducted using Membrane Filtration Technique. The data were analyzed using Statistical Package for Social Science (SPSS V20) and Microsoft Excel 2011 (Mac version).

\section{Results AND Discussions}

Results from the study indicated that $63(45 \%)$ of the total number of respondents used GWCL piped water as their primary source of water for drinking, $49(35 \%)$ used borehole, $21(15 \%)$ used sachet water and $7(5 \%)$ used different sources of water (students bring water from their various homes) as their primary source of drinking water. About 78(55\%) of the respondents used GWCL water for other activities, 49(35\%) used borehole water for other activities, and 14(10\%) used different sources of water for other activities (Table 1).

Every pupil should use a minimum of 5 liters of water during school hours but quite a number of schools selected did not have adequate water for students to drink and wash their hands (UNICEF, 2012; WHO, 2011). Inadequate water for drinking might lead to a detrimental effect on the health of school children (Chard et al. 2019; McMichael, 2019). Insufficient water for drinking also means inadequate water for proper hygiene delivery (Ray, 2020; Carter et al., 1999; Islam et al. 2020). According to WHO, the source of water must be within $100 \mathrm{~m}$ from the collection point and the collection time should not exceed 30 minutes (Howard et al., 2003; UN, 2010). Though the time used by the respondents who fetched water from accessible points around the schools were all less than the WHO recommended time, there were respondents who did not have access to the accessible water points in the school premises. If a school does not have a functional water facility within the schools premises, children will have to walk a long distance to fetch water, this might contaminate the water upon reaching the school, such actions might create health risks (Jasper et al. 2012; WHO, 2008). Such situation is likely to affect water consumption pattern among school children (Franse et al. 2019) and also reduce their active learning periods in class and their absorption rate due to tiredness.

Table 1: Respondents' response on the sources of water

\begin{tabular}{llc}
\hline Parameter & Responses & N (\%) \\
\hline Primary source of water for drinking & GWCL piped water & $63(45)$ \\
& Borehole water & $49(35)$ \\
& Sachet water & $21(15)$ \\
& Other sources & $7(5)$ \\
Source of water for other activities & Borehole water & $48(34.3)$ \\
& GWCL piped water & $78(55.7)$ \\
& Other sources & $14(10)$ \\
Adequacy of water & Yes & $140(100)$ \\
Accessibility of water & No & $14(10)$ \\
& Yes & $126(90)$ \\
Responsibility of fetching water & & \\
& Each class & $54(38.7)$ \\
Equipment for fetching water & All students & $80(57.1)$ \\
& Class 5 & $6(4.2)$ \\
Duration for fetching water & Bowl & $7(5)$ \\
& Bucket and gallon & $133(95)$ \\
& $1-5$ minutes & $113(80.7)$ \\
& 5-10 minutes & $20(14.2)$ \\
& $10-15$ minutes & $4(2.9)$ \\
& $15-20$ minutes & $3(2.1)$ \\
\hline
\end{tabular}


Interview with heads of the basic schools indicated that $19(95 \%)$ of the twenty schools had functional water facilities within the school, while $1(5 \%)$ had no water facility within the school. Out of the 19 schools with functional water facility, 13(65\%) had no measures (bowls for fetching water, presence or absence of cover lid, environmental hygiene, etc.) to keep their functional water facility clean, 7(35\%) had measures in keeping their functional water facility clean. Observation made in the schools that had no measures to keep their water clean also indicated that the workers as well as the pupils used different water drawing bowls that were dirty for fetching water from the water receptacles. Water has high potential to be polluted during collection, storage and fetching from containers (Amenu, Spengler, André, \& Zárate, 2014). According to UNICEF, an estimated 1.9 billion school days could be gained if the Millennium Development Goals (MDGs) related to safe water supply and sanitation are achieved and the incidence of diarrhoeal illness is reduced (Hutton et al., 2004). Water was not accessible to physically challenged students for $12(63.2 \%)$ of the schools whilst $7(36.8 \%)$ had water accessible to physically challenged students (Table 2). About $55 \%$ of the heads indicated that they experienced a shortage of water in a month with reasons being broken pipelines and taps not flowing, while $45 \%$ said they never experienced any shortage in a month (Table 2 ). Shortage of water could lead to improper cleaning of eating bowls of students and cooking bowls while at the same time preventing adequate hand washing by students (Nuwagaba et al., 2020). According to McMichael C. (2019), a literature review of water, sanitation and hygiene (WASH) in schools in lowincome countries indicated that ensuring access to safe and sufficient water and sanitation and hygiene promotion in schools has great potential to improve health and education.

Table 2: Interviews with Heads of the Selected Basic Schools

\begin{tabular}{llc}
\hline Parameter & Responses & N (\%) \\
\hline Functional water facility near the school & No & $1(5)$ \\
& Yes & $19(95)$ \\
Measures to maintainclean water facility & No & $13(65)$ \\
Accessibility of water to students & Yes & $7(35)$ \\
& No & $1(5)$ \\
Accessible to physically challenge & Yes & $19(95)$ \\
Shortage of water in the last one month and reason & No & $12(63.2)$ \\
If Yes, reason & Yes & $7(36.8)$ \\
& Broken pipeline & $71(55)$ \\
& Tap not flowing & $4(20)$ \\
Reliability of water source & No & $9(45)$ \\
& Excellent & $3(15)$ \\
& Good & $16(80)$ \\
\hline
\end{tabular}

\section{Availability of WASH Facilities}

Preventing the spread of infectious agents in schools is a good way regarding abating the infectious diseases among children. Providing water, sanitation, and hygiene (WASH) facilities in schools are very crucial in ensuring the adoption and maintenance of safe sanitation and hygiene practices among school children (Appiah-Brempong et al. 2018; UN, 2010). Results from the study indicated that $105(75 \%)$ of the respondents had toilet facilities in their school whilst 35 $(25 \%)$ indicated that they had no toilet facility in their schools. The absence of toilet facilities in school could be a cause for open defecation by the school children which could likely lead to the spread of infectious diseases which can lead to morbidity and absenteeism in schools (Jasper et al., 2012). Moreover, about 25 $(23.8 \%)$ of the students who had toilets in their schools did not use the toilets, based on aesthetically displeasing reasons of bad odour, toilets soiled with faeces and the presence of too many students (Table 3). These are clear underscoring factors of poor management of the school toilets which could contribute to open defecation in the school environment and poor personal hygiene for the students. These could be a recipe for polluting the water used for the school feeding because the students after using the poorly managed toilets or open defecation might come back to contaminate the water through handling. Though the toilet might be present in the schools, they might not be adequate for the number of students in the school. This was established in respect of the student population in the affected schools and the available number of toilets. The standard practice for the use of toilet facilities in schools is one toilet per 20 students but according to the National implementation model for WASH in schools for Ghana Education Service, a maximum of 50 pupils should use one toilet hole per toilet cubicle (Thorn 2017; Ghana Education Service, 2012). With the availability of a hand washing facility, $126(90 \%)$ of the respondents had hand washing facilities in their schools while $14(10 \%)$ had none in their schools. Though most of the basic schools had hand washing facility they were inadequate, $2(1.4 \%)$ had only one hand washing device, $8(5.7 \%)$ had two, $40(28.6 \%)$ had three and 
$76(54.3 \%)$ had four. Inadequate hand washing facilities is likely to lead to poor hand hygiene practices (Behailu et al. 2016). However, studies have established that poor hand hygiene practices potentially contribute to community-based infections which include gastrointestinal, skin and respiratory infections (Crosby et al. 2020). A study which looked at the impact of poor hand hygiene in college students specifically found a link between poor hand hygiene practices to increased occurrences of infectious diseases, medical visits and absence from class and work (Prater, 2016). On students understanding of when (moments) hand should be washed, 29(20.7\%) indicated before and after eating only, $38(27.1 \%)$ said after playing only while 59 $(42.1 \%)$ mentioned different critical times. These responses from the students clearly indicated that most of them lacked the understanding of handwashing education which could contribute to the failure of the school feeding programme to achieve its ultimate goal.

Table 3: Availability of hand washing facilities in schools

\begin{tabular}{|c|c|c|}
\hline Parameter & Responses & $\mathbf{N}(\%)$ \\
\hline \multirow[t]{2}{*}{ Availability of toilet facility } & No & $35(25)$ \\
\hline & Yes & $105(75)$ \\
\hline \multirow[t]{3}{*}{ Type of toilet facility } & VIP & $26(18.7)$ \\
\hline & KVIP & $78(55.7)$ \\
\hline & Pit latrine & $1(0.7)$ \\
\hline \multirow[t]{2}{*}{ Use of school toilet } & Yes & $80(76.2)$ \\
\hline & No & $25(23.8)$ \\
\hline \multirow[t]{3}{*}{ Reasons for not using school toilet } & Smelling (bad odour) & $10(40)$ \\
\hline & Highly soiled with faeces & $9(36)$ \\
\hline & Too many students present & $6(24)$ \\
\hline \multirow[t]{2}{*}{ Hand washing facility in a school } & No & $14(10)$ \\
\hline & Yes & $126(90)$ \\
\hline \multirow[t]{4}{*}{ Number of hand washing facilities } & One & $2(1.4)$ \\
\hline & Two & $8(5.7)$ \\
\hline & Three & $40(28.6)$ \\
\hline & Four & $76(54.3)$ \\
\hline \multirow[t]{3}{*}{ No. of times you wash your hands } & 2 times & $29(20.7)$ \\
\hline & 3 times & $38(27.1)$ \\
\hline & 4 times & $59(42.1)$ \\
\hline \multirow[t]{3}{*}{ Moments hand washing is needed } & Before \& after eating only & $29(20.7)$ \\
\hline & After playing only & $38(27.1)$ \\
\hline & Critical moments $* * *$ & $59(42.1)$ \\
\hline
\end{tabular}

***Before, during, and after preparing food, before eating food, before and after caring for someone who is sick, before and after treating a cut or wound, after using the toilet, after changing diapers or cleaning up a child who has used the toilet, after blowing your nose, coughing, or sneezing, after touching an animal, after touching garbage

\section{Physicochemical Quality of the Water Used in Schools}

The physicochemical and microbial quality of the water used in the schools under the school feeding programme in Mampong Municipal were carefully sampled and analyzed to determine how these could impact on the health of the pupils and the success of the school feeding. The results of these laboratory studies are presented in Table 4.

pH

The $\mathrm{pH}$ of pure water is referred to as the measure of hydrogen ions concentration in water which ranged from 0 to 14 . In general, water with a $\mathrm{pH}$ of 7 is considered neutral while $\mathrm{pH}$ lower than 7 is referred to as acidic and a $\mathrm{pH}$ greater than 7 known as basic. The lowest and highest $\mathrm{pH}$ were recorded in Nyinampong and Assam (5.02 \pm 1.59 and 6.23 \pm 0.25 respectively (Table 4). According to WHO standards, the $\mathrm{pH}$ of the water should be 6.5 to 8.5 . This implied that all the water samples taken from the selected schools were acidic showing $\mathrm{pH}$ value below the permissible limit (6.5 - 8.5). Mohsin et al (2013) noticed that low $\mathrm{pH}$ in water from Bahawalpur City tends to be toxic and with a high degree of $\mathrm{pH}$ it turned into the bitter taste. Basically, the low $\mathrm{pH}$ might be due to the amount of dissolved carbon dioxide (CO2), which forms carbonic acid in water (Edimeh et al. 2011). Water with low pH has the potential to dissolve ions from its metal containers especially cooking bowls made from aluminum which are the common types used for cooking in Ghana (Jabeen et al. 2016).

\section{Turbidity}

Turbidity is important in determining the quality of drinking water as it can create a Conducive environment for microbes to escape the disinfection process (Soros et al. 2019). The turbidity of the water samples ranged from $0.11 \pm 0.95-1.84 \pm 0.16$ NTU, although the ideal limit of turbidity is $1 \mathrm{NTU}$, the maximum desirable limit set by WHO is 5 NTU. 
Therefore the turbidity of water from the sampled schools was within acceptable limits.

\section{Electrical conductivity $(\mu \mathrm{S} / \mathrm{cm})$}

The amount of dissolved solids in water determines the electrical conductivity. An increase in ion concentration increases the electrical conductivity of water. High conductivity also means an increase in salinity. Electrical conductivity (EC) actually measures the ionic process of a solution that enables it to transmit current. According to WHO standards, the EC value of drinking water should not exceed $400 \mu \mathrm{S} / \mathrm{cm}$ (Rakib et al., 2020). However, the conductivity of all the drinking water samples collected from the schools ranged from $54.97 \pm 3.06$ - 376.87 \pm 91.2 , which indicated the presence of some ionic solutions in water but were good for drinking.

\section{Total dissolved solids (TDS) (mg/l)}

Water is able to dissolve a wide range of inorganic and some organic minerals or salts such as potassium, calcium, sodium, bicarbonates, chlorides, magnesium, sulfates, etc from its environment. These dissolved minerals can produce un-wanted taste, odour and color in water. This is an important parameter for the use of water. The average value of TDS in the water samples of the selected schools ranged from 19.67 \pm 2.59 - 204.47 $\pm 36.10 \mathrm{mg} / \mathrm{L}$ (Table 4). WHO desirable limit is $500 \mathrm{mg} / \mathrm{l}$ whilst the maximum permissible level is 2000 $\mathrm{mg} / \mathrm{l}$ (Jothiavenkatachalam et al., 2010). TDS values observed in water samples from the schools were within the desirable limit. These findings were similar to the results of studies conducted by Salifu et al. (2015) and Sebiawu et al. (2014) which found average TDS of groundwater for drinking from Upper West and Northern regions to be $200 \mathrm{mg} / \mathrm{l}$.TDS in water may be associated with concentrated wastewater from both residential and rainfall-runoff. Drinking water with a high TDS level above the EPA standard causes undesirable taste and gastrointestinal irritation (Patil et al., 2012).

\section{Total hardness (mg/l)}

It is not caused by a single substance but by a variety of dissolved polyvalent metallic ions, predominantly calcium and magnesium cations. Hard water is characterized by high mineral contents that are usually not harmful to humans. It is often measured as calcium carbonate $\left(\mathrm{CaCO}_{3}\right)$ because it consists mainly of calcium and carbonates the most dissolved ions in hard water. In the study areas, the hardness of the water sampled ranged from $9.45 \pm 3.44$ to $180 \pm 118.23 \mathrm{mg} / \mathrm{l}$ (Table4). Any water which contains calcium carbonate at concentrations below $60 \mathrm{mg} / \mathrm{l}$ is described as soft; $60-120 \mathrm{mg} / \mathrm{l}$, is moderately hard; $120-180 \mathrm{mg} / \mathrm{l}$, is hard; and more than $180 \mathrm{mg} / \mathrm{l}$, is very hard (McGowan, 2000). According to World Health Organization (WHO), the total hardness of drinking water should be $500 \mathrm{mg} / \mathrm{l}$ and the results clearly indicate that total hardness of water samples from the schools was within the WHO standards and therefore suggesting that it is not harmful for consumption by the students.

\section{Temperature $\left({ }^{\circ} \mathrm{C}\right)$}

The temperature of the water samples ranged from $29.33 \pm 0.58{ }^{\circ} \mathrm{C}$ to $31.67 \pm 0.58{ }^{\circ} \mathrm{C}$ (Table 4). A rise in temperature of water leads to an increase in chemical reactions in water, reducing the solubility of gases, especially, oxygen which affects its taste and odour (Kale, 2016). There is no specific guideline on drinking water temperature but it is noted that increasing temperatures above room temperature makes it increasingly unpleasant to consumers and encourages microbial growth (Rhoads, et al., 2015; WHO, 2009). According to the American College of Sports Medicine, water, and other drinks should be between 10 and $22.2^{\circ} \mathrm{C}$ for optimal hydration (Meyer et al., 2019). Though the drinking water used by the schools had comparatively higher temperatures, by the standards of American College of Sports Medicine, it could not be said to be bad since ambient temperature in the tropical environment dictates that, provided there is no microbial growth.

Table 4: Physico-chemical parameters of drinking water samples of schools in Mampong

\begin{tabular}{lcccccc}
\hline \multicolumn{1}{c}{ Town } & \multicolumn{3}{c}{ Parameter } & \multicolumn{2}{c}{ Total } & $\begin{array}{c}\text { Temperature } \\
(\mathbf{0} \mathbf{C})\end{array}$ \\
\cline { 2 - 7 } & $\mathbf{p H}$ & $\begin{array}{c}\text { Turbidity } \\
(\mathbf{N T U})\end{array}$ & $\begin{array}{c}\text { Conductivity } \\
(\boldsymbol{\mu S} / \mathbf{c m})\end{array}$ & $\begin{array}{c}\text { Total Dissolved } \\
\text { Solids }(\mathbf{m g} / \mathbf{l})\end{array}$ & $\begin{array}{c}\text { Hardness } \\
(\mathbf{m g} / \mathbf{l})\end{array}$ \\
\hline Kyirimfaso & $5.31 \pm 1.60$ & $1.84 \pm 0.16$ & $101.19 \pm 4.46$ & $35.84 \pm 3.26$ & $9.45 \pm 3.44$ & $30.33 \pm 1.15$ \\
Nyinampong & $5.02 \pm 1.59$ & $0.93 \pm 0.56$ & $253.25 \pm 8.98$ & $19.67 \pm 2.59$ & $180.87 \pm 118.23$ & $31.67 \pm 0.58$ \\
PSK & $5.44 \pm 1.48$ & $1.69 \pm 0.97$ & $376.87 \pm 91.2$ & $204.47 \pm 36.10$ & $12.67 \pm 1.15$ & $29.33 \pm 1.15$ \\
Krobo & $5.68 \pm 0.45$ & $1.71 \pm 0.18$ & $172.47 \pm 2.51$ & $30.45 \pm 0.97$ & $10.73 \pm 0.70$ & $30.50 \pm 0.87$ \\
Ninting & $5.47 \pm 0.30$ & $0.48 \pm 0.11$ & $54.97 \pm 3.06$ & $36.02 \pm 1.42$ & $23.27 \pm 0.61$ & $29.33 \pm 1.15$ \\
Bosofour & $5.39 \pm 0.42$ & $0.11 \pm 0.95$ & $55.12 \pm 18.74$ & $34.65 \pm 4.60$ & $20.87 \pm 5.67$ & $29.67 \pm 0.58$ \\
Assam & $6.23 \pm 0.25$ & $1.33 \pm 0.83$ & $76.63 \pm 1.52$ & $42.69 \pm 2.73$ & $28.20 \pm 3.65$ & $31.00 \pm 1.72$ \\
Mampong & $5.89 \pm 0.3$ & $1.17 \pm 0.28$ & $197.50 \pm 6.10$ & $88.28 \pm 1.21$ & $47.60 \pm 3.03$ & $31.00 \pm 1.00$ \\
Kofiase & $5.47 \pm 0.59$ & $0.26 \pm 0.08$ & $55.92 \pm 24.96$ & $27.38 \pm 12.10$ & $26.00 \pm 11.91$ & $29.33 \pm 0.58$ \\
Benim & $6.18 \pm 0.32$ & $1.49 \pm 0.17$ & $73.38 \pm 2.62$ & $37.11 \pm 1.24$ & $21.93 \pm 3.06$ & $31.00 \pm 1.72$ \\
WHO Guideline & $\mathbf{6 . 5}-\mathbf{8 . 5}$ & $\mathbf{1 - 5}$ & & $\mathbf{5 0 0}-\mathbf{2 0 0 0}$ & $\mathbf{5 0 0}$ & - \\
\hline
\end{tabular}


Microbial Quality of Water Used in Schools.

The microbial parameters of water were based on Total coliform and faecal coliform. Results from the study on the presence of Total coliform in the drinking water ranged from nil to $37.67 \pm 19.66 \mathrm{cfu} / 100 \mathrm{ml}$. Water samples taken from $7(70 \%)$ of the towns in the study area had Total coliforms ranging from $0.67 \pm 0.58$ $\mathrm{cfu} / 100 \mathrm{ml}$ to $37.67 \pm 19.66 \mathrm{cfu} / 100 \mathrm{ml}$ which exceeded the maximum permissible load $(0 / 100 \mathrm{cfu} / \mathrm{ml})$ for drinking water (Table 5). The presence of total coliforms in water indicates inadequate treatment or contamination from the ambient environment and is associated with gastrointestinal diseases (Shafqat et al., 2018).The study confirmed the presence of faecal coliforms in most of the water samples tested. Faecal coliform counts in water from all sources ranged from
$4.33 \pm 4.51 \mathrm{cfu} / 100 \mathrm{ml}-11.67 \pm 7.64 \mathrm{cfu} / 100 \mathrm{ml}$. The results suggested that the quality of the water as indicated were not good because for water to be considered to have no risk to human health, the faecal coliforms counts $/ 100 \mathrm{ml}$ and total coliform counts $/ 100$ $\mathrm{ml}$ should be zero (Tesfaye, 2015). This standard has also been prescribed by the Ghana Standard Authority (GSA) and WHO standards. Although total coliform might not always be directly related to the presence of faecal contamination or pathogens in the drinking water, this study found that most of the water samples contained both total coliform and faecal coliform. Most of the water samples were not wholesome for drinking by the school children. Continuous drinking of water from such sources could affect the health of the students and derail the gains of the school feeding program.

Table 5: Microbial analysis of drinking water samples of schools

\begin{tabular}{lcc}
\hline Towns & \multicolumn{2}{c}{ Parameter } \\
\cline { 2 - 3 } & $\begin{array}{c}\text { Total Coliform } \\
\text { (Cfu/ } \mathbf{1 0 0 m l})\end{array}$ & $\begin{array}{c}\text { Fecal coliform } \\
\text { cfu/100ml }\end{array}$ \\
\hline Kyirimfaso & $13.67 \pm 11.02$ & $11.67 \pm 7.64$ \\
Mampong & NIL & NIL \\
Krobo & $15.00 \pm 3.00$ & NIL \\
Ninting & $4.00 \pm 4.58$ & $4.57 \pm 2.52$ \\
Kofiase & $8.33 \pm 7.64$ & $2.67 \pm 2.52$ \\
Assam & $20.00 \pm 7.00$ & $4.33 \pm 4.51$ \\
Nyinampong & $0.67 \pm 0.58$ & NIL \\
Bosofour & NIL & NIL \\
PSK & NIL & NIL \\
Benim & $37.67 \pm 19.66$ & $4.00 \pm 2.00$ \\
WHO Guideline & NIL & NIL \\
\hline
\end{tabular}

\section{CONCLUSION}

A number of schools in the study area did not have hand washing facilities to make them wash their hands and even where present, the facilities were not adequate for those who had it. Therefore their hand washing practices were affected by the inadequate availability of facilities, and their knowledge of hand washing. Some schools in the study areas had the challenge of shortage of water which could affect the feeding and the health of the school children. The $\mathrm{pH}$ of the drinking water types in the schools studied was too low as compared to the standards recommended by WHO and EPA, which could affect the quality of the water used for preparing the food and health of the children. The microbial quality of the water used in most of the schools did not meet the international microbial water quality standards and could be a recipe for health implications for the pupils.

\section{Acknowledgements}

The author of this article wishes to acknowledge the group of BSc Integrated Science students of the 2018/2019 academic year students who were hired as field data collectors gather the data from the various schools in the Mampong Municipality. This study would not have been complete without their field work.

\section{Funding}

The research received no funding.

\section{Conflict of Interest}

The author declares no conflict of interest.

\section{REFERENCE}

1. Amenu, K., Spengler, M., André, M., \& Zárate, A. V. (2014). Microbial quality of water in rural households of Ethiopia: implications for milk safety and public health. Journal of health, population, and nutrition, 32(2), 190.

2. Appiah-Brempong1, E., Harris, M. J., Newton, S. \& Gulis, G. (2018). Examining school-based hygiene facilities: a quantitative assessment in a Ghanaian municipality. BMC Public Health (2018) 18:581 https://doi.org/10.1186/s12889-018-5491-9. 
3. Arnold, B. F. \& Colford, J. M, Jr. (2007). Treating water with chlorine at point-of-use to improve water quality and reduce child diarrhea in developing countries: a systematic review and meta-analysis. The American journal of tropical medicine and hygiene 76: 354.

4. Behailu B, Hailu G, Dawit C, Abebech A, Amelmal K, Engida K, et al. Assessment of Hand Washing Practice and it ${ }^{\text {te }} \mathrm{s}$ Associated Factors among First Cycle Primary School Children in Arba Minch Town, Ethiopia. Int J Community Med Public Health. 2016 ;3(10):2958-66.

5. Carter, R. C., Tyrrel, S. F., \& Howsam, P. (1999). The impact and sustainability of community water supply and sanitation programmes in developing countries. Water and Environment Journal, 13(4), 292-296.

6. Chard, A. N., Trinies, V., Edmonds, C. J., Sogore, A., \& Freeman, M. C. (2019). The impact of water consumption on hydration and cognition among schoolchildren: Methods and results from a crossover trial in rural Mali. PloS one, 14(1), $\mathrm{e} 0210568$.

7. Crosby, S., Laird, K., \& Younie, S. (2020). Children and handwashing: Developing a resource to promote health and well-being in low and middle income countries. Health Education Journal, 79(2), 123-137.

8. Cutler, D., \& Miller, G. (2005). The role of public health improvements in health advances: The twentieth-century United States. Demography 42: $1-22$.

9. Dufour, A. P. (2003). Assessing microbial safety of drinking water: Improving approaches and methods: International Water Assn.

10. Edimeh et al (2011) Physico-chemical parameters and some Heavy metals content of rivers Inachalo and Niger in Idah, Kogi State. J Chem Soc Nigeria 36(1):95-101

11. Fewtrell, L., Kaufmann, R. B., Kay, D., Enanoria, W., Haller, L., et al. (2005). Water, sanitation, and hygiene interventions to reduce diarrhoea in less developed countries: a systematic review and metaanalysis. The Lancet infectious diseases 5: 42-52.

12. Franse, C. B., Wang, L., Constant, F., Fries, L. R., \& Raat, H. (2019). Factors associated with water consumption among children: a systematic review. International Journal of Behavioral Nutrition and Physical Activity, 16(1), 64.

13. Ghana Education Service (School Health Education Programme Unit). Wash in schools (wins). Annual report, December, 2012.

14. Ghana Statistical Service. (2010). Population and Hosing Census, District analytical report, Ghana

15. Howard, G., Bartram, J., Water, S., \& World Health, O. (2003). Domestic water quantity, service level and health: World Health Organization.

16. Hutton, G., Haller, L., Water, S., \& World Health, O. (2004). Evaluation of the costs and benefits of water and sanitation improvements at the global level: Geneva: World Health Organization.

17. Islam, A. R. M. T., Siddiqua, M. T., Zahid, A., Tasnim, S. S., \& Rahman, M. M. (2020). Drinking appraisal of coastal groundwater in Bangladesh: An approach of multi-hazards towards water security and health safety. Chemosphere, 126933.

18. Jabeen, S., Ali, B., Khan, M. A., Khan, M. B., \& Hasan, S. A. (2016). Aluminum Intoxication through Leaching in Food Preparation. Alexandria Science Exchange Journal, 37(4), 618-626.

19. Jasper C., Thanh-Tam L., Bartram J. (2012). Water and Sanitation in Schools: A Systematic Review of the Health and Educational Outcomes. Int. J. Environ. Res. Public. 9:2772-2787.

20. Jothivenkatachalam, K., Nithya, A., \& Mohan, S. C. (2010). Correlation analysis of drinking water quality in and around Perur block of Coimbatore District, Tamil Nadu, India. Rasayan Journal of Chemistry, 3(4), 649-654.

21. Kale, V. S. (2016). Consequence of temperature, $\mathrm{pH}$, turbidity and dissolved oxygen water quality parameters. International Advanced Research Journal in Science, Engineering and Technology, 3(8), 186-190

22. McGowan W (2000) Water processing: residential, commercial, light-industrial, 3rd ed. Lisle, IL, Water Quality Association

23. McMichael C. (2019). Water, Sanitation, and Hygiene (WASH) in Schools in Low-Income Countries: A Review of Evidence of Impact. Int $J$ Environ Res Public Health.; 16(3): 359.

24. Meyer, F., Timmons, B. W., Wilk, B., \& Leites, G. T. (2019). Water: hydration and sports drink Nutrition and Enhanced Sports Performance (pp. 545-554): Elsevier.

25. Mohsin, M., Safdar, S., Asghar, F. \& Jamal, F. (2013). Assessment of Drinking Water Quality and its Impact on Residents' Health in Bahawalpur City. International Journal of Humanities and Social Science, 3(15); 114-128

26. Monney I, Martinson OS, Asampana AM, Albert M (2014). Assessing hand hygiene practices in schools benefiting from the Ghana School Feeding Programme. Sci. J. Publ. Health 2(1):7-14.

27. Nuwagaba, J., Ashok, D. D., Balizzakiwa, T., Kisengula, I., Nagaddya, E. J., \& Rutayisire, M. (2020). The era of Coronavirus; knowledge, attitude, practices, and barriers to hand hygiene among Makerere University students and Katanga Community residents. medRxiv.

28. Patil. P.N, Sawant. D.V, Deshmukh. R.N (2012). Physico-chemical parameters for testing of water A review. International Journal of Environmental Sciences Volume 3(3), 1194-1207.

29. Prater, K. J., Fortuna, C. A., Janis , M. L., Brandeberry, M. S., Stone, A. R., \& Lu, X. (2016). Poor hand hygiene by college students linked to more occurrences of infectious diseases, medical 
visits, and absence from classes. American Journal of Infection Control, 44, 66-70

30. Rakib, M. A., Sasaki, J., Matsuda, H., Quraishi, S. B., Mahmud, M. J., Bodrud-Doza, M., . . . Bhuiyan, M. A. H. (2020). Groundwater salinization and associated co-contamination risk increase severe drinking water vulnerabilities in the southwestern coast of Bangladesh. Chemosphere, 246, 125646.

31. Ray, I. (2020). Viewpoint: Handwashing and COVID-19: Simple, right there...?. World Development, 105086.

32. Rhoads, W. J., Pearce, A., Pruden, A., \& Edwards, M. A. (2015). Anticipating the effects of green buildings on water quality and infrastructure. Journal-American Water Works Association, 107(4), 50-61.

33. Salifu M, Aidoo F, Hayford MS et al (2015) Evaluating the suitability of groundwater for irrigational purposes in some selected districts of the Upper West region of Ghana. Appl Water Sci. DOI: $10.1007 / \mathrm{s} 13201-015-0277-\mathrm{Z}$

34. Sebiawu EG, Fosu SA, Saana SBBM (2014) A physicochemical and bacteriological analysis of borehole water samples from the Wa Municipality of the Upper West Region, Ghana

35. Shafqat, M., Batool, A., \& Kazmi, S. S. (2018). Drinking water quality, water distribution systems and human health: a microbial evaluation of drinking water sources in salt range. Int J Hydro, 2(5), 542-547.

36. Soros, A., Amburgey, J. E., Stauber, C. E., Sobsey, M. D., \& Casanova, L. M. (2019). Turbidity reduction in drinking water by coagulationflocculation with chitosan polymers. Journal of Water and Health, 17(2), 204-218.
37. Tesfaye, K. (2015). Water Quality and Sanitation Status of Improved Drinking Water Sources in selected rural areas of Southern Nations Nationalities Peoples Region, Ethiopia.

38. Thorn, P. (2017, November 15). School toilets: Guidance and regulations. Retrieved September 02, 2020, from https://www.sec-ed.co.uk/bestpractice/school-toilets-guidance-and-regulations/

39. UNICEF (2008). Sanitation and Water for All: A Global Framework for Action WASH Ghana.

40. UNICEF 2012 Raising even more clean hands: advancing learning, health and equity through WASH in schools. Joint call to action. [Online] Available: www.unicef.org/wash/schools/ files/Raising_Even_More_Clean_Hands_Web_17_ October_2012(1).pdf [Accessed 15 April 2020].

41. United Nations, Office of the High Commissioner for Human Rights (OHCHR). General Comment No. 15: The Right to Water (Arts. 11 and 12 of the Covenant). Geneva: OHCHR; 2010.

42. WHO (2009), "Water, sanitation and hygiene standards for schools in low-cost settings", (http://whqlibdoc.who.int/publications/2009/97892 41547796_eng.pdf?ua=1, accessed 10 April 2020).

43. WHO Geneva. Guidelines for drinking water quality. 3rd edi. 1: 438, 2008.

44. WHO. (2011). Guidelines for drinking-water quality, fourth edition. Geneva: World Health Organization.

45. World Health Organization. (2010). World health statistics2010. World Health Organization. Retrieved on May20 ,2020 fromhttps://apps.who.int/iris/handle/10665/44292.

46. World Health Organization. (2013). World health statistics2013. World Health Organization. https://apps.who.int/iris/handle/1066 $\underline{5 / 81965 .}$ 